TOMASZ SAHAJ

Pracownia Filozofit i SocjologiI

Akademia Wychowania Fizycznego w Poznaniu

E-MAIL:SAHAJ@AWF.POZNAN.PL

\title{
CHOROBA, NIEPEŁNOSPRAWNOŚĆ I STAROŚĆ JAKO PROBLEM EGZYSTENCJALNY, FILOZOFICZNY I SPOŁECZNY
}

\author{
Motto: \\ „Życie jako śmiertelna choroba przenoszona droga płciową”.
}

„Choroba jest nocną półkulą życia, naszym bardziej uciążliwym obywatelstwem. Od dnia narodzin każdy z nas posiada bowiem jakby dwa paszporty - przynależy zarówno do świata zdrowych, jak i do świata chorych".

Susan Sonntag, Choroba jako metafora [1999: 7]

\section{Filozofia i medycyna w paradygmacie kultury europejskiej}

Jednym z fundamentów kultury europejskiej jest filozofia, której zręby powstawały niemal 3 tys. lat temu w starożytnej Grecji - jako konstytutywny element zaawansowanej kultury cielesnej i duchowej, której granicę wyznaczały igrzyska olimpijskie i dobrze rozwinięta medycyna; z kinezyterapią włącznie. Twórcami pierwszych szkół filozoficznych, a zarazem pierwszych europejskich szkół wyższych w ogóle, był: w przypadku Akademii - Platon potężnie zbudowany olimpijczyk, bokser i zapaśnik, a w przypadku Liceum - jego równie rosły uczeń - Arystoteles - lekarz ze szlachetnego rodu lekarzy królewskich, przez wiele lat będący osobistym guwernerem Aleksandra Macedońskiego, zwanego „Wielkim”, który pomimo młodego wieku militarnie zdobył 3/4 ówczesnego świata. Władcę, którego Arystoteles nauczył nie tylko samoobsługi własnego ciała w chorobie, w kontuzjach i w zakresie opatry-

1 Tytuł filmu, według scenariusza i w reżyserii Krzysztofa Zanussiego, 2000 rok. 
wania ran (krewki imperator zawsze walczył na czele swej armii), ale i wrażliwości społecznej (Aleksander swych zasłużonych i „wyeksploatowanych” żołnierzy odsyłał na „emeryturę”). Filozofię w jednej z antycznych szkół studiował drobno zbudowany Hipokrates, „ojciec medycyny”, którego przysięgę do dziś składają lekarze. Wielu starożytnych filozofów było lekarzami - ciała i duszy. Galen z Pergamonu twierdził wręcz: „Dobry lekarz jest jednocześnie filozofem" [Galen, 1990: 449-458].

Choroba, niepełnosprawność, starość i śmierć są składnikami ludzkiej egzystencji i w naturalny sposób do nich podchodzono w antycznej refleksji filozoficznej. Tajemnicą poliszynela było to, że twórca "Szkoły w ogrodzie” - Epikur - miał problemy zdrowotne z żołądkiem. Biografowie i historycy zwracali szczególną uwagę na kwestie cielesności opisywanych postaci. W stosunkowo niewielkim mieście, jakimi były Ateny w czasie powstawania pierwszych szkół filozoficznych (czyli ok. 2,5 tys. lat temu) powszechnie wiadomym było, kto na co choruje i jakiego rodzaju dokuczają mu dolegliwości. Zważywszy na fakt, że większość wolnych obywateli (mężczyzn) mniej lub bardziej regularnie uczęszczało do obiektów sportowych, w których ćwiczono całkowicie nago, a uczestnictwo w życiu publicznym (agora, teatr, sąd) wymagało osobistego stawiennictwa (dodatkowo ubrania podkreślały budowę i kształt ciała), nie sposób było ukryć anomalii fizycznych.

Ci, którzy próbowali to robić (jak Perykles swą monstrualnie wielką głowę pod nakryciem) stawali się obiektem drwin. Plutarch z Cheronei tak scharakteryzował Peryklesa: „Było to dziecko normalnej budowy fizycznej, poza tym, że miało głowę wydłużoną i niewspółmiernie wielką. Dlatego to na wszystkich prawie podobiznach Perykles przedstawiany jest $\mathrm{z}$ hełmem na głowie. Artyści nie chcieli, jak się zdaje, narażać go na śmieszność" [Plutarch z Cheronei, 2004: 59]. Co innego, gdy ktoś pokonywał swą chorobę lub niepełnosprawność - jak „ojciec logopedii” - Demostenes - żmudnymi i niewdzięcznymi ćwiczeniami na plaży poprawiającymi wadę wymowy. Czy też Hysmon z Elidy, o którym Pauzaniasz napisał, że „uzyskał jako zawodnik w pięcioboju jedno zwycięstwo w Olimpii, drugie w Nemei (...). W dzieciństwie cierpiał na zanik muskułów wskutek gośćca oraz że z tej przyczyny zajął się ćwiczeniami w pentatlonie, aby dzięki trudom stać się mężczyzną zdrowym i odpornym na chorobę. Te ćwiczenia miały mu przygotować w przyszłości szereg olśniewających zwycięstw” [Pauzaniasz, 1968: 140].

Ciało - piękne, sprawne, zdrowe, wysportowane - było w starożytnej Grecji rodzajem legitymacji społecznej, cielesnym identyfikatorem, świadczącym o statusie społecznym obywatela [Sahaj, 2011: 385-390]. Opisując 
dziś kogoś prominentnego zwracamy uwagę na jego ubranie, status materialny, a w przypadku naukowców - dorobek (liczba i jakość publikacji) pomijając wygląd zewnętrzny (chyba, że zdecydowanie odbiega od standardów, jak w przypadku Stephena Hawkinga czy Temple Grandin). Leszek Kołakowski prawie całe życie chodził o lasce, ale był przede wszystkim filozofem, Philip G. Zimbardo chodzi o lasce, ale jest przede wszystkim psychologiem społecznym. Natomiast w opisach antycznych filozofów zawsze zawarty jest komponent cielesności. W przypadku myśliciela Menedemosa mamy taką charakterystykę postaci: „Do późnej starości zachował dobrą kondycję fizyczną. Ciało miał silne, jędrne i opalone od przebywania na powietrzu niczym atleta. Wzrostu był średniego, takim też ukazuje go posążek, znajdujący się na starym stadionie w Eretrii; rzeźbiarz, na pewno celowo, przedstawił go nie w szatach, ale prawie nago, pokazując niemal całe ciało" [Diogenes Laertios, 1988: 154]. Wszyscy bogowie w mitologii greckiej (poza jedynym wyjątkiem w osobie kulawego Hefajstosa) posiadali cechy najbardziej wówczas pożądane: byli sprawni cieleśnie i świetnie zbudowani - tak ich sobie wyobrażano i tak ich uwieczniono w rzeźbach. „Gdy zaś od połowy $\mathrm{V}$ wieku [p.n.e. - dopisek T.S.] nauka grecka poprzez medycynę wkroczy w sferę wychowania fizycznego i sportowej agonistyki, lekarze staną się głównymi krytykami zawodowej agonistyki, widząc w niej nie źródło zdrowia, lecz przyczynę chorób i demoralizacji” [Biliński, 1956: 289].

Sokrates, na obrazie Jacques-Louis Davida przestawiony jest jako 70-latek o ciele takim, jakim nie powstydziłby się dziś nastolatek; ciele wyrzeźbionym ćwiczeniami fizycznymi. Po śmierci Sokratesa na znak żałoby zamknięto na kilka dni ośrodki sportowe. Ciało jednak, zwłaszcza z wiekiem, odmawia posłuszeństwa, a sport nie jest antidotum na wszystkie chorobowe dolegliwości. Greccy filozofowie nie tyle wprowadzili, bo ten zwyczaj już istniał dużo wcześniej i był szeroko rozpowszechniony, ile rozpropagowali samobójstwo związane $z$ chorobą nieuleczalną, bądź stanem psychofizycznym, uznawanym przez danego człowieka za niezadawalający [Hołówka, 2001]. W opisach obecnych i starożytnych historyków filozofii znajdujemy mnóstwo przykładów mędrców, którzy zdecydowali się na odebranie sobie życia. Więcej jeszcze, istniało oczekiwanie społeczne, że w skrajnych przypadkach tak właśnie należy postąpić. Przykładem tego jest spotkanie dwóch filozofów: Speuzypa z Aten, po założycielu Akademii, Platonie (który dożył 81 lat), jej dyrektora - całkowicie sparaliżowanego, niesionego na wykłady na lektyce oraz cynika Diogenesa, mieszkającego w beczce w Atenach. Speuzyp „pewnego razu wieziony na małym wóz- 
ku do Akademii spotkał po drodze Diogenesa i pozdrowił go, ten odparł: "Ale ja nie pozdrawiam ciebie, który godzisz się na życie w takim stanie». W końcu w podeszłym wieku, będąc w stanie depresji, odebrał sobie życie" [Diogenes Laertios, 1988: 216]. Popularność i społeczne przyzwolenie na samobójstwo, w tym wspomagane przez innych, utrzymywało się w kulturze europejskiej do końca starożytności: do upadku Cesarstwa Rzymskiego i dojściu do władzy chrześcijan w IV w. n.e. Święty Augustyn, z wahaniem, lecz jednak, wprowadził do kulturowego i filozoficznego obiegu całkowity zakaz popełniania samobójstwa, który w Kościele katolickim obowiązuje bezwzględnie do dziś. Tworząc pewnego rodzaju paradygmat kulturowo-społeczny, rzutujący na myśl europejską, filozofię i medycynę.

\section{Choroba, starość i śmierć jako problem filozoficzny i społeczny $\mathrm{XX} / \mathrm{XXI}$ wieku}

Dziś chorzy, niepełnosprawni, starzy i umierający sytuują się poza granicami głównej narracji filozoficznej i życia społecznego, a problematykę $\mathrm{z}$ nimi związaną w dużym stopniu przejęła bioetyka. Odseparowani od rodzin - rodzimy się, chorujemy i umieramy w szpitalach - oddani pod opiekę wyspecjalizowanych gałęzi medycyny jako ,jednostki chorobowe” i „przypadki medyczne", poddani sfarmakolizowanej, stechnicyzowanej i ulaboratyjnionej „nauce medycznej”. Leczącej „incydenty chorobowe”, w procesie usuwania których nie ma miejsca na wzgląd na całego człowieka, jego uczucia, niepokoje i strach, a rozmowa $\mathrm{z}$ nim (lub chwila milczenia), potrzymanie za rękę (lub posiedzenie u wezgłowia pacjenta) - holistyczne podejście - należą do dóbr luksusowych i wyjątków. O tym, że pacjenci chętnie i dobrowolnie idą do szpitala, możemy przeczytać jedynie w utopiach filozoficznych Platona (twórcy idei sanatorium), Tomasza Morusa (zwolennika samobójstwa wspomaganego), Franciszka Bacona (zwolennika eutanazji), czy Tomasza Campanelli (rzecznika racjonalizacji medycyny). Platon trzeźwo opisał i ocenił „złych lekarzy”, a jego opis bynajmniej nie stracił aktualności: „Biegają po mieście lub siedząc w szpitalu czekają na chorych. Tacy lekarze nie udzielają pacjentom żadnych wyjaśnień dotyczących ich choroby i słowem nie dają odezwać się choremu (...) niby jakiś tyran, i co tchu pędzi do następnego pacjenta" [Platon, 1960: 166].

Socjolog Elżbieta Zakrzewska-Manterys uważa, że intelektualnie niepełnosprawni plasują się dziś wręcz poza granicami społeczeństwa. Pisze ona: „Upośledzeni umysłowo mają innych adwokatów niż chorzy psychicznie. 
Adwokatami chorych psychicznie są filozofowie, wielcy humaniści podejmujący najistotniejsze, fundamentalne kwestie dotyczące kondycji ludzkiej czy sensu istnienia. Stąd dyskurs o chorych psychicznie jest jednym $\mathrm{z}$ ważnych wątków współczesnej kultury, jest to dyskurs publiczny, w którym głos zabierają autorytety moralne naszych czasów. Adwokatami upośledzonych umysłowo są raczej urzędnicy systemu, ludzie działający w enklawie upośledzenia. Ich głos nie przedostaje się poza tę enklawę. Upośledzeni umysłowo są obcy publiczności, a problematyka upośledzenia nie wpisuje się, na ogół, w dyskurs o egzystencjalnych problemach ludzkości” [Zakrzewska-Manterys, 2010: 140-141]. A jeśli już, to ludzie z niepełnosprawnościami znajdują się marginesie życia społecznego, czy też, jak sugerują autorzy jednej z prac, w „rezerwacie przestrzeni publicznej” [Gajdzica, 2013], są „naznaczonymi” społecznie, stygmatyzowanymi outsiderami, dewiantami (w sensie społecznym) - jak twierdzi Howard S. Backer [2009]. Są „inni”, „obcy”, „wyalienowani”; zwłaszcza, gdy ze względu na chorobę pragną umrzeć [Wach, 2010: 141-157].

Natomiast ludzie dotknięci chorobą nowotworową, której towarzyszy przerażające odium śmiertelności, jednej z naszych głównych zabójców, „cesarza wszechchorób” [Mukherjee, 2013], są traktowani w sposób ich uprzedmiatawiający. Rak, zdaniem Susan Sonntag, przejął dziś odium ciążące niegdyś na grú́licy, a następnie na AIDS. Pisze ona: „Chorym na raka kłamie się nie tylko dlatego, że choroba jest (albo przynajmniej tak się uważa) wyrokiem śmierci, lecz również dlatego, że widzi się w niej coś obscenicznego - w pierwotnym znaczeniu tego słowa: coś złowrogiego, ohydnego, porażającego zmysły. Choroba serca to słabość, rodzaj awarii mechanicznej; nie ma $\mathrm{w}$ niej nic żenującego, nic $\mathrm{z}$ tabu, które otaczało niegdyś gruźlików, a dziś otacza chorych na raka. Metaforyka gruźlicy i raka przywołuje procesy biologicznie szczególnie szokujące i odrażające" [Sonntag, 1999: 12]. Informacja o raku (zwykle podana w sposób beznamiętny i „suchy”, co ma świadczyć o obiektywizmie i profesjonalizmie lekarza) wywołuje w człowieku kierkegaardowską „bojaźń i drżenie” (bo to beznadziejna „choroba na śmierć”?), heideggerowską trwogę bycia-ku-śmierci, indukuje cioranowskie pytania o (bez)sens życia. Młody filozof Marcin Fabjański ujął rzecz precyzyjnie: „Pacjenci chorzy na raka skarżą się często na to, że chodzą od specjalisty do specjalisty, bo jeden odsyła ich do drugiego. Każdy przepisuje leki na różne przypadłości, a oni nie maja nawet pojęcia, czy te pigułki nie znoszą nawzajem swojego działania. Wiedzą za to, że kiedy już je wszystkie połkną - co w Polsce w wypadku starszych ludzi oznacza 
zazwyczaj, że zabraknie im pieniędzy na książkę lub wyjście do kawiarni wcale nie zrobi im się lepiej. Czują też, że z tak poszatkowanym systemem leczenia jest coś nie tak. I marzą, żeby było jak w dawnych czasach, kiedy jeden lekarz opiekował się nimi przez lata i znał doskonale nie tylko ich organizm, lecz także potrzeby emocjonalne" [Fabjański, 2014: 41].

Rację mają Michel Foucault [1999] i Zygmunt Bauman [1998], uznając chorobę za fenomen kulturowy i konstrukt społeczny. Susan Sonntag pisząc o nowotworach posunęła się nawet do twierdzenia: „choroba jako metafora” [1999: 7]. Choroba, starość, śmierć są fundamentalnymi problemami filozoficznymi, a obecnie również bardzo poważnymi problemami społeczno-ekonomicznymi. Klasyk współczesnej filozofii niemieckiej, uczeń Martina Heideggera i Edmunda Husserla - Hans Georg Gadamer wyraził to tak: „Nie powinno przy tym dziwić, że filozof, który sam nie jest lekarzem, ani nie czuje się pacjentem, zabiera głos w sprawie społecznie tak istotnej, wyłaniającej się z stosunku do służby medycznej w epoce tryumfu nauki i techniki. Nigdzie indziej postęp nowoczesnego badania naukowego nie wkracza tak silnie w pole napięć społeczno-politycznych typowych dla naszych czasów, jak w tym obszarze. (...). Bardzo mocno dotyczy to też nad chorymi i nad ludźmi starszymi. Coraz poważniej brany rachunek ekonomiczny domaga się, by uznać opiekę zdrowotną ponownie za ogólne zadanie całego społeczeństwa" [Gadamer, 2011: 7-8].

Dyskurs na temat choroby, autonomii i godności człowieka, jego władzy nad swoim życiem oraz możliwości samodzielnego zakończenia go własnymi rękoma (o ile jest to fizycznie możliwe), lub przy pomocy asystentów, ożywiły po II wojnie światowej koncepcje takich postaci, jak filozofowie Jan Szewczyk, Henryk Elzenberg i Tadeusz Kotarbiński, lekarze Christiaan Barnard (dokonał pierwszego przeszczepu serca) [Barnard, 1996] i Tadeusz Kielanowski oraz socjologowie: medycyny, jak Antonina Ostrowska [2005], czy prawa, jak Brunon Hołyst [2012]. Wiele zamieszania wprowadziły „podania” i „prośby o śmierć” [Humbert 2004; Świtaj 2008] oraz realizacje tego typu próśb wykonywane przez takich kontrowersyjnych lekarzy, jak Jack Kevorkian (nazywany „Dr Śmierć”), czy szwajcarska klinika „Dignitas". W 1997 roku grupa szacownych i znanych przedstawicieli amerykańskiej liberalnej filozofii społecznej ${ }^{2}$ złożyło w federalnym Sądzie Najwyższym USA dokument nazwany „amicus curie” (dosł. „przyjaciel sądu”),

2 Ronald Dworkin, Thomas Nagel, Robert Nozick, John Rawls, Thomas Scanlon i Judith Jarvis Thomson. Autorzy ci jednocześnie opublikowali tekst The Philosophers' Brief w „New York Review of Books", wyjaśniając swoje intencje liczniejszym odbiorcom. 
w którym zażądali do wprowadzenia do konstytucji prawa gwarantującego (w pakiecie świadczeń medycznych i socjalnych) śmierć. Nie życie - śmierć! Tak, aby każdy obywatel miał konstytucyjne prawo do śmierci i w każdej chwili (jeśli jego decyzja byłaby dostatecznie mocno umotywowana i uzasadniona - jak prośba o eutanazję w Holandii) mógł z niego skorzystać. W USA wzrasta też liczba osób, które domagają się prawa do śmierci i pragną świadomie umrzeć, zanim choroba Alzheimera pozbawi ich możliwości samodzielnego decydowania o sobie i autonomicznych decyzji [Gillies, 2012, passim].

Tymczasem w świetle doktryny Kościoła katolickiego samobójstwo jest przestępstwem (jak również pomoc przy nim w majestacie polskiego prawa), a wspomaganie osób próbujących odebrać sobie życie jest niedopuszczalne $\mathrm{z}$ moralnego i etycznego punktu widzenia. Bioetyk i filozof medycyny Tadeusz Ślipko informuje: „życie ludzkie jest autoteliczną wartością moralną, a przeto samą w sobie godną szacunku i ochrony, czyli w moralnym sensie niepogwałcalną" [Ślipko, 1997: 21]. Filozof, święty, papież Jan Paweł II, w tej kwestii wypowiadał się nadzwyczaj zdecydowanie: „stanowczo potępiam w imieniu całego Kościoła te przestępstwa (...): Wszystko, co godzi w samo życie, jak wszelkiego rodzaju zabójstwa, ludobójstwa, spędzanie płodu, eutanazja i dobrowolne samobójstwo" [Jan Paweł II, 1997: 9].

\section{Choroba, niepełnosprawność i śmierć w prozie współczesnej}

Choroba, niepełnosprawność, starość i śmierć - te naturalne elementy i punkty węzłowe ludzkiej egzystencji, jak traktował je niemiecki filozof i psychiatra Karl Jaspers, stanowiące „odwieczny” kanon filozofii i literatury. W jednym z platońskich dialogów Sokrates z pełną swobodą zadaje leciwemu człowiekowi „stojącemu nad grobem” pytania dotyczące jego stanu psychofizycznego i zbliżającej się śmierci. Cyceron i cesarz-filozof Marek Aureliusz napisali jedne z najpiękniejszych utworów o przemijaniu i starości. Ze stoickim spokojem do nadchodzącej śmierci na skutek nieuleczalnej choroby nowotworowej podchodzi młodociany bohater książki Oscar i pani Róża, Erica-Emmanuela Schmitta - filozofa, który filozofii się wyparł, by o trudnych rzeczach pisać prosto (a nie odwrotnie). Choroba, agonia i śmierć są „bohaterkami” takich klasycznych utworów, jak pisane w łóżku przez obłożnie chorego Marcela Prousta $W$ poszukiwaniu straconego czasu, Tomasza Manna Czarodziejska góra, Gustawa Flauberta Pani Bovary, czy Lwa Tołstoja Śmierć Iwana Iljicza. 
Dziś te kulturowe i społeczne fenomeny, jakimi jest choroba, niepełnosprawność i śmierć, są na nowo „odkrywane”, opisywane, (re)interpretowane i „oswajane”, jak określiłby to Philippe Ariès [2011] lub Michel Vovelle [2008]. Te (re)interpretacje nierzadko są w zaskakujących aspektach i kontekstach, z całej bogatej i szerokiej palety możliwości. Joseph Heller, autor prześmiewczego Paragrafu 22, wydał żartobliwą autobiograficzną powieść Nic śmiesznego o nagłym zachorowaniu na Zespół Guillaina-Barrégo, wielomiesięcznej hospitalizacji i rehabilitacji, która doprowadziła go do finansowej ruiny. Jerzy Stuhr refleksyjnie i z pokorą podszedł do bezpośrednio go dotykającego nie-śmiertelnego „incydentu nowotworowego” w autobiograficznej pracy Tak sobie myślę, następnie użyczając swojego głosu do czytania audiobooków prac filozoficznych o chorobie i śmierci podanych na wesoło [Cathart, Klein, 2009, 2012]. Brytyjski historyk Tony Judt - całkowicie sparaliżowany przez ostatnie lata swego życia przez chorobę nazwaną od nazwiska słynnego amerykańskiego sportowca - Henry'ego Lou Gehriga - dyktował skrybie swoje refleksje, podobnie jak uczynił to Stephen Hawking, pisząc swoje bestsellerowe prace. Analogicznie uczyniła dotknięta tą samą chorobą neurodegeneracyjną co Hawking - stwardnieniem zanikowym bocznym (ALS) - szwedzka prezenterka telewizyjna - z każdym dniem ograbiana przez chorobę z możliwości ruchowych [Lindquist, 2006].

W polskiej literaturze, autorstwa pisarzy z „najwyższej półki”, nominowanych i nagradzanych prestiżowymi nagrodami, w tym literacką nagrodą Nike, nie brakuje przenikliwych prac opowiadających chorobę, relacjonowaną niemal na gorąco, $\mathrm{z}$ dnia na dzień, chwila po chwili. Idealnym przykładem są oba Dzienniki Jerzego Pilcha [2012, 2014], skrupulatnie i ze swadą oraz bolesną autoironią pisane od momentu, w którym intensyfikują się dolegliwości związane z chorobą Parkinsona. W obu tych pracach nie brakuje porównań choroby do meczów piłki nożnej i kibicowania, gdyż Pilch jest oddanym kibicem futbolowym (krakowskiej Cracovii). Autor kilkudziesięciu bestsellerowych prac - Janusz Leon Wiśniewski - w niemal każdej swojej książce opisuje postaci chore i niepełnosprawne. W najnowszej powieści Grand szczegółowo scharakteryzował frustrację i wściekłość profesora belwederskiego dotkniętego parkinsonizmem, prowokującego go do reakcji ucieczkowych i myśli o samobójstwie. Przerażonego cyklicznymi przejawami choroby, zamykającego się na całe dnie i noce na poddaszu swojego domu, upijającego się, rozgoryczonego i samotnie trawiącego swą traumę. Rodzina nie miała wówczas do niego dostępu i trzymała się od niego z daleka. „Joachim Maria Pokuta czuł się przez całe życie niedoskonały, 
a niepotrzebne dążenie do doskonałości zżerało go jak złośliwy nowotwór. (...). Parkinsona stwierdzono u niego, gdy miał czterdzieści dziewięć lat. (...). Teraz ma prawie sześćdziesiąt. Ogólnie biorąc, nie powinien narzekać, bywa gorzej. Joachim ciągle potrafi przez kilkanaście sekund utrzymać butelkę przy ustach. Cierpli wprawdzie na drżenie spoczynkowe, spowolnienie i zubożenie ruchów, niekiedy ma maskowatą twarz, zaburzenia powonienia, napadowe pocenie się i ten wstrętny ślinotok. Ale jest to na dzisiaj do opanowania i potrafi wszystko ukryć. (...). Jedyne, co go wykańczało, to ta okropna dyzartria. Mówił jak z kluskami w ustach, niewyraźnie, afonicznie. Jak pijak spod budki z piwem. Przestał się kłócić z żoną i dziećmi, kiedy zauważył, że swoimi bełkotliwymi tyradami może ich jedynie rozśmieszyć" [Wiśniewski, 2014: 275-276].

Opisywany profesor nie mogąc wyleczyć choroby, ani zminimalizować jej dolegliwości (Jerzemu Pilchowi wszczepiono w mózg elektrody zmniejszające dyskomfort), próbował ją oswoić i „rehabilitować”. Czytamy: „Dyzartrii «za diabła nie da się opanować». Tak powiedział mu pewien uznawany za guru polskiej neurologii profesor z Gdańska. Ale on - sam profesor belwederski - innym profesorom z zasady nie dowierzał. Przez wiele tygodni, wieczorami, kiedy już wszyscy poszli do domów, zamykał się w swoim biurze na uniwersytecie i godzinami powtarzał słowo «kurwa», nagrywał na dyktafon, a potem odsłuchiwał. Wściekał się za każdym razem, gdy wychodziła mu «kulwa». Obojętnie jak się starał, nie potrafił już poprawnie «kurwić». Ostatnimi czasy bywało jeszcze gorzej. «Kulwa» zamieniła się w «gulwa» lub co gorsza w «hulfa». Panował nad samogłoskami, ale spółgłoski z reguły tracił w bełkocie. Co ciekawe, działo się tak tylko wtedy, gdy mówił po polsku. Kiedy śpiewał swoich ulubionych Floydów lub Cockera po angielsku, ze słowami nie działo się nic nienormalnego. Wychodziły mu z ust pięknie, tak jak trzeba, i samogłoski, i spółgłoski. Jak w szczęśliwych czasach przed «Parksym», bo tak nazywał swoją chorobę" [Wiśniewski, 2014: 276].

\section{„Antidotum” na nieuchronną śmierć}

Zastanawiające są prace tych filozoficznie zorientowanych myślicieli, którzy w obliczu nieubłaganej śmierci postanowili z faktograficzną dokładnością i protokolarną precyzją opisać ostatnie etapy życia niszczonego przez nieuleczalną chorobę. Jeden $\mathrm{z}$ nich - amerykański krytyk literacki Anatole Broyard - w pracy o symptomatycznym tytule: Upojony choroba. 
Zapiski o życiu i śmierci napisał: „(...) wiadomość o raku była jak porażenie prądem. Jak galwanizacja. Stałem się innym człowiekiem. Całe moje przyziemne «ja» rozpłynęło się, została tylko esencja. Zacząłem na nowo widzieć świat" [Broyard, 2010: 53]. Podobne w duchu, choć stworzone w innym stylu, są refleksje świadomego zbliżania się starości i rychłej śmierci socjologa Brunona Synaka, zaprezentowane w pracy Bezsens $i$ sens choroby nieodwracalnej [2014], z licznymi fotografiami i płytą CD, na której można usłyszeć głos autora i na filmie zobaczyć jego samego, jakby pragnącego mocniej i trwalej zostawić część siebie w arystotelesowskim logosie. Wyrafinowany prozaik Wojciech Kuczok, ustami swojego umierającego bohatera, wyartykułował wiele mówiące zdania: „(...) śmiertelnie chorzy nie jęczą z bólu, tylko z żalu, że ból nigdy nie mówi «żegnaj», zawsze «tymczasem», «na razie», «bywaj»; «bywaj» to najperfidniejsze z pożegnań, ból wie, że śmiertelnie chorzy już nie są, tylko bywają; zdrowi żyją ciągle, chorzy tylko w czasie przejaśnień, ich życie pękło, czas przejaśnień jest czasem zbierania coraz drobniejszych fragmentów, prób ich sklejania; śmiertelnie chorzy są zdrowi tylko we fragmentach, w kawałkach, już się nie zdarzy, żeby wszystkie ich fragmenty były jednocześnie gotowe do życia" [Kuczok, 2008: 90-91].

„Być gotowym do życia”, żyć w sposób autentyczny, to, zdaniem takich filozofów-egzystencjalistów, jak francuscy nobliści Albert Camus i Jaen Paul Sartre oraz Martin Heidegger (bez nagrody Nobla), istnieć w zgodzie ze świadomością swojej śmierci i mając ją jako horyzont swojej egzystencji. Uświadomienie sobie kruchości ludzkiego istnienia, które jest według Blaise'a Pascala łamliwe jak „trzcina myśląca”, w najbardziej dramatyczny i fundamentalny sposób następuje w konfrontacji ze swoją skończonością. Znakomicie artykułują to refleksyjnie nastawieni lekarze, którym uświadomiły to incydenty, w wyniku których oni sami - medycy - trafili do szpitalnych łóżek. Przykładem jest lekarz-naukowiec i filozof medycyny Andrzej Szczeklik [2007, 2012], jak też wybitny brytyjski neurolog Oliver Sacks, autor licznych renomowanych publikacji z zakresu medycyny w ujęciu społecznym. Psycholog społeczny Wiesław Łukaszewski [2011] po zawale opisał strategie „ucieczki przed śmiercią”, w szczególności poprzez aktywność fizyczną i sport. Tym samym wrócił do korzeni i nawiązał do poglądów i zaleceń tych filozofów, którzy byli zarówno lekarzami, jak i sportowcami. Jak olimpijczyk Platon, lekarz królewski Arystoteles, czy też, jakże odmiennych filozofów, ale znanych z umiłowania do antycypacyjnej i profilaktycznej, regularnej i systematycznej aktywności fizycznej, takich jak: Immanuel Kant, Søren Kierkegaard, Jean Jacques Rousseau, Bertrand Russell i Jan Paweł II. 


\section{Bibliografia}

Ariès P. (2011)., Człowiek i śmierć, tłum. E. Bąkowska, Warszawa, Wydawnictwo "Aletheia".

Backer H.S. (2009), Outsiderzy. Studia z socjologii dewiacji, tłum. O. Siara, Warszawa, PWN.

Barnard Ch. (1996), Godne życie, godna śmierć, tłum. J. K. Kelus, Warszawa, Wydawnictwo „Jacek Santorski \& Co" i Wydawnictwo „Cis”.

Bauman Z. (1998), Śmierć i nieśmiertelność. O wielości strategii życia, tłum. N. Leśniewski, Warszawa, PWN.

Biliński B. (1956), Antyczni krytycy antycznego sportu, „Meander”, t. XI, nr 9.

Broyard A. (2010), Upojony chorobą. Zapiski o życiu i śmierci, tłum. A. Nowakowska, Wołowiec, Wydawnictwo „Czarne”.

Cathart T., Klein D. (2012), Heidegger i hipopotam ida do nieba. O życiu, śmierci i zaświatach na serio $i$ w żartach, tłum. K. Puławski, Poznań, Wydawnictwo „Media Rodzina".

Cathart T., Klein D. (2009), Przychodzi Platon do doktora. Filozofia $w$ żartach, tłum. K. Puławski, Poznań, Wydawnictwo „Media Rodzina”.

Diogenes Laertios (1988), Żywoty i poglądy słynnych filozofów, tłum. I. Krońska i in., Warszawa, PWN.

Fabjański M. (2014), Zaufaj życiu. Nie zakochuj się w przelatującym wróblu, Warszawa, PWN.

Foucault M. (1999), Narodziny kliniki, tłum. P. Pieniążek, Warszawa, Wydawnictwo KR.

Gadamer H. G. (2011), O skrytości zdrowia, tłum. A. Przyłębski, Poznań, Media Rodzina.

Gajdzica Z. (red.) (2013), Człowiek $z$ niepełnosprawnościa w rezerwacie przestrzeni publicznej, Kraków, Wydawnictwo „Impuls”.

Galen (1990), Dobry lekarz jest jednocześnie filozofem, tłum. M. Szarmach, „Filomata”, nr 400.

Gąciarz B. (red.) (2014), Niepetnosprawność. Wyzwania teorii i praktyki, „Studia Socjologiczne", nr 2.

Gillies A. (2012), Opiekunka: życie z Nancy. Podróż w świat Alzheimera, tłum. Z. Zawadzki, Wołowiec, Wydawnictwo „Czarne”.

Hołowka J. (2001), Etyka w działaniu, Warszawa, Wydawnictwo „Pruszyński i S-ka”.

Hołyst B. (2012), Suicydologia, Warszawa, Wydawnictwo „LexisNexis”.

Humbert V. (2004), Proszę o prawo do śmierci, tłum. A. Nowak, Poznań, Wydawnictwo „Assimil”.

Jan Paweł II (1997), Evangelium vitae. Tekst i komentarze, T. Styczeń i J. Nagórny (red.), Lublin, Redakcja Wydawnictw KUL.

Kuczok W. (2008), Senność, Warszawa, Wydawnictwo „WAB”.

Lindquist U-C. (2006), Wiosłować bez wioseł. Książka o życiu i śmierci, tłum. B. Walczak-Larsson, Warszawa, Wydawnictwo „Jacek Santorski \& Co” i „Agencja Wydawnicza".

Łukaszewski W. (2011), Udręka życia. Jak ludzie radzą sobie z lękiem przed śmiercią, Sopot, Wydawnictwo „Smak słowa”. 
Mukherjee S. (2013), Cesarz wszech chorób: biografia raka, tłum. J. Dzierzgowski i A. Pokojska, Wołowiec, Wydawnictwo „Czarne”.

Na olimpijskiej bieżni i w boju: z Pauzaniasza wędrówki po Helladzie księgi V, VI i IV, (1968), tłum. J. Niemirska-Pliszczyńska, Wrocław, Wydawnictwo „Ossolineum”.

Ostrowska A. (2005), Śmierć w doświadczeniu jednostki i społeczeństwa, Warszawa, Wydawnictwo IFiS PAN.

Pilch J. (2014), Drugi dziennik. 21 czerwca 2012 - 20 czerwca 2013, Kraków, Wydawnictwo Literackie.

Pilch J. (2012), Dziennik, Warszawa, Wydawnictwo „Wielka Litera”.

Platon (1960), Prawa, tłum. M. Maykowska, Warszawa, PWN.

Plutarch z Cheronei (2004), Żywoty sławnych mężów, tłum. M. Brożek, t. 1, Wrocław, Wydawnictwo Ossolineum i DeAgnosti.

Sahaj T. (2011), The Body as a Form of ID and Social Differentiation (in Ancient Greece), "Human Movement", t. 12, nr 4.

Ślipko T. (1997), Newralgiczne punkty bioetyki. Klucze rozstrzygnięć, (w:) M. Renkielska (red.), Pacjent u schyłku XX wieku, z. 3, Kielce, Wydawnictwo „Jedność”.

Sonntag S. (1999), Choroba jako metafora. AIDS i jego metafory, tłum. J. Anders, Warszawa, PIW.

Świtaj J. (2008), 12 oddechów na minutę, Kraków, Wydawnictwo „Otwarte”.

Synak B. (2014), Bezsens i sens choroby nieodwracalnej, Gdańsk, Wydawnictwo „Zrzeszenie Kaszubsko-Pomorskie".

Szczeklik A. (2007), Kore. O chorych, chorobach i poszukiwaniu duszy medycyny, Kraków, Wydawnictwo „Znak”.

Szczeklik A. (2012), Nieśmiertelność. Prometejski sen medycyny, Kraków, Wydawnictwo „Znak”.

Vovelle M. (2008), Śmierć w cywilizacji Zachodu. Od roku 1300 po współczesność, tłum. T. Swoboda i in., Gdańsk, Wydawnictwo „Słowo/Obraz terytoria”.

Wach B. (2010), Chory, proszący o śmierć, jako Inny, (w:) L. Dziewiecka-Bokun, A. Śledzińska-Simon (red.), Społeczeństwo wobec Innego. Kategoria Innego w naukach społecznych i życiu publicznym, Toruń, Wydawnictwo „Adam Marszałek”.

Wiśniewski L. J. (2014), Grand, Warszawa, Wydawnictwo „Wielka Litera”.

Zakrzewska-Manterys E. (2010), Upośledzeni umysłowo. Poza granicami społeczeństwa, Warszawa, Wydawnictwo Uniwersytetu Warszawskiego. 
SUMMARY

\section{Sickness, disability and old age as an existential, philosophical and social problem}

The aim of the talk is the presentation of disease, disability and old age in threefold depiction. Firstly, as a philosophical issue that has been niggling philosophers since antiquity, in which the foundations of medicine were created by Hippocrates. Secondly, as a problem of contemporary, humanistic thinkers (doctors, philosophers, sociologists) struggling with these issues as the intimate and personal problem. Thirdly, the analysis of the autobiographical works of writers, affected by the effects of incurable disease and/or disability, examining inevitably forthcoming death in the context of sense and nonsense of human existence.

\section{Keywords:}

sickness, disability, old age, medicine, philosophy, literature 